\title{
Production of Bacillus licheniformis ATCC 21415 alkaline protease in batch, repeated batch and continuous culture
}

\author{
Samia A. Ahmed and Ahmed F. Abdel-Fattah \\ Department of Chemistry of Natural and Microbial Products \\ National Research Center, Dokki, Cairo, Egypt. \\ E-mail: dr_sa_ahmed@yahoo.com
}

Received 8 July 2009; received in revised form 28 September 2009; accepted 6 December 2009

\begin{abstract}
Bacillus licheniformis ATCC 21415 cells were immobilized on different carriers using different methods of immobilization including physical adsorption, covalent binding, ionic binding and entrapment. The immobilized cells were prepared by covalent binding on wool (as a new carrier) through $1 \%$ glutaraldehyde had the highest enzyme activity $(9.0 \mathrm{U} / \mathrm{mL})$ with the highest specific productivity $(6.17 \mathrm{U} / \mathrm{g}$ wet cells/h). Alkaline protease production and the stability of biocatalyst were investigated in both free and immobilized cells. The results showed that the immobilized cells were more efficient for enzyme production by repeated batch fermentation ( 5 cycles, $480 \mathrm{~h}$ ) with $57 \%$ residual activity whereas the free cells retained $35 \%$ after 2 cycles. In continuous production the highest enzyme activity $(9.9 \mathrm{U} / \mathrm{mL})$ was obtained at a dilution rate of $0.1 / \mathrm{h}$ while the highest enzyme yield $(763.6 \mathrm{U} / \mathrm{h})$ and the highest reactor productivity $(3.32 \mathrm{U} / \mathrm{mL} / \mathrm{h})$ were attained at a dilution rate of $0.4 / \mathrm{h}$. Packed-bed bioreactor was a successful method for continuous production of alkaline protease for a long time $(168 \mathrm{~h})$ with $53 \%$ relative activity. The bioreactor affected the highest specific productivity (118.2 U/g wet cells/h) which was 12-24 times higher than other systems of enzyme production.
\end{abstract}

Keywords: B. licheniformis, immobilization, batch, repeated batch and continuous cultures

\section{INTRODUCTION}

Alkaline proteases are one of the most widely studied group of enzymes due to their use in many industrial applications such as in food, pharmaceutical, leather, detergent and in recovering silver from used X-ray films (Singh et al., 2004). Another important application of proteases is to break down protein tissue in order to be able to extract a particular substance, such as heparin (Beshay and Moriera, 2003). Bacilli are well suited for industrial enzymes production due to their ability to secrete large amounts of protein directly into the medium (Harwood, 1992). Thirty to forty of the production cost of industrial enzymes is estimated to be accounted by the cost of the growth media (Joo et al., 2002).

Industrial proteases are normally produced in fedbatch cultivation with prolonged period of intermediate and low specific growth rates. Immobilization of microbial cells for enzyme production offers various advantages, such as the ability to separate cell mass from the bulk liquid for possible reuse, facilitating continuous operation over a prolonged period and decreasing contamination from the product stream during continuous fermentations without loss in biomass (Helmo et al., 1985; Beshay, 2003; Karandikar et al., 2006). Immobilized cells could increase productivity and operational stability or reduce the delays involved in enzyme production (Zhang et al., 1989; Galazzo and Bailey, 1990). Moreover, immobilized cells can show modifications in physiology and biochemical composition when compared with suspended cells (Adinarayana et al., 2004).

The application of immobilized cells for the production of metabolic products by microorganisms has been widely studied and several valuable products such as enzymes, organic acids, amino acids, steroids, alcohol and antibiotics have been successfully obtained (Guo et al., 1990; Adinarayana et al., 2004; Prabakaran and Hoti, 2008). Wool is an attractive and suitable as an immobilization matrix because it is cheap, available and non-toxic. The purpose of the present investigation was to study the immobilization of $B$. licheniformis ATCC 21415 cells for higher alkaline protease production using different methods on different carriers. The reusability of immobilized cells for alkaline protease production under batch, repeated batch and continuous fermentation were also investigated.

\section{MATERIALS AND METHODS}

\section{Bacterial strain}

B. licheniformis ATCC 21415 was obtained from the American Type Culture Collection, USA. The culture was maintained on nutrient agar medium at $30^{\circ} \mathrm{C}$ for $48 \mathrm{~h}$ and stored at $4{ }^{\circ} \mathrm{C}$. 


\section{Fermentation media}

The optimized medium was used for alkaline protease production and composed of $(\mathrm{g} / \mathrm{L}):\left(\mathrm{NH}_{4}\right)_{2} \mathrm{SO}_{4}, 1.0$; $\mathrm{KH}_{2} \mathrm{PO}_{4}, 0.5 ; \mathrm{CaCO}_{3}, 1.0$; dextrin, 35.0; $\mathrm{NaCl}, 1.0$ and peptone, 1.0. The components of the medium were dissolved in $5 \%$ wheat bran extract. The $\mathrm{pH}$ was adjusted to 7.0 before autoclaving. Each $250-\mathrm{mL}$ Erlenmeyer flask contained $25 \mathrm{~mL}$ of medium and $2 \%(\mathrm{v} / \mathrm{v}) 24 \mathrm{~h}$-old inoculum. The preparation of inoculum was done by adding $2 \mathrm{~mL}$ of sterile distilled water to 24 -h old slants, which were scratched and transferred to each $250-\mathrm{mL}$ Erlenmeyer flask. The flasks were incubated in a rotary shaker regulated at $6000 \mathrm{rev} / \mathrm{min}$ and $37^{\circ} \mathrm{C}$ for $96 \mathrm{~h}$. The bacterial cells were harvested by centrifugation in a refrigerated centrifuge at $5000 \mathrm{rev} / \mathrm{min}, 15 \mathrm{~min}, 4^{\circ} \mathrm{C}$. The clear culture filtrates were assayed for enzyme activity and protein content.

\section{Assay of enzyme activity}

Caseinase activity was estimated according to the method of Bergkvist (1963), by determining the amount of casein hydrolysis. For each test, $1 \mathrm{~mL}$ of enzyme solution was incubated at $37^{\circ} \mathrm{C}$ for 10 min with $1 \mathrm{~mL}$ of casein solution $(1.5 \% \mathrm{w} / \mathrm{v}$ in $50 \mathrm{mM}$ glycine $\mathrm{NaOH}$ buffer at $\mathrm{pH} 9.5)$. One unit $(U)$ of enzyme activity was taken as the amount of enzyme that liberated $1 \mu \mathrm{mol}$ of tyrosine per $\mathrm{mL}$ per minute. At least three measurements were made for each experiment and the data given are an average of these results.

\section{Protein determination}

Total protein concentrations were determined by the method of Lowry et al. (1951) using bovine serum albumin as a standard.

\section{Carriers for cell immobilization}

Sodium alginate, agar, chitosan and $k$-carrageenan were supplied from Sigma Chemical Co., USA. Loofa, sponge and stainless steel were collected from the local market. While wool (Lambs wool) was a personal specimen imported from France.

\section{Cell immobilization procedures}

All the immobilization processes were performed under aseptic conditions. The cell pellets of $B$. licheniformis ATCC 21415 obtained in logarithmic phase of growth was collected by centrifugation (5000 rev/min, $15 \mathrm{~min}$ ) in a refrigerated centrifuge.

\section{Entrapment in Ca-alginate}

Bacterial cells obtained from $50 \mathrm{~mL}$ culture $(0.38 \mathrm{~g}$ weight wet) were mixed with $10 \mathrm{~mL}$ sodium alginate solution at a concentration of $3 \%(\mathrm{w} / \mathrm{v})$ through a sterile $5 \mathrm{~mL}$ pipette. Gel beads of approximately $2 \mathrm{~mm}$ diameter were obtained.
The beads were obtained by dropping mixtures into sterile $\mathrm{CaCl}_{2}(0.1 \mathrm{M})$ through a sterile $5 \mathrm{~mL}$ pipette. Gel beads of approximately $2 \mathrm{~mm}$ diameter were obtained. The beads from $10 \mathrm{~mL}$ gel (150 beads) were used for inoculation of $25 \mathrm{~mL}$ of the production medium (Jamuna and Ramakrishna, 1992).

\section{Entrapment in agar and k-carrageenan}

The wet cells obtained from $50 \mathrm{~mL}$ culture $(0.38 \mathrm{~g}$ weight wet) were mixed with $10 \mathrm{~mL}$ of $3 \%(\mathrm{w} / \mathrm{v})$ agar or $k$ carrageenan solution at $45^{\circ} \mathrm{C}$. The mixture was quickly cooled at $4{ }^{\circ} \mathrm{C}$, cut into $2 \times 2 \times 2 \mathrm{~mm}$ fragments and transferred to $25 \mathrm{~mL}$ of the production medium (Cheetham et al., 1985).

\section{Covalent binding}

One gram of each tested carrier (loofa, wool and stainless steel) approximately $1 \times 1 \mathrm{~mm}$ fragments and was treated with $10 \mathrm{~mL}$ of $1 \%$ glutaraldehyde overnight. The treated carriers were collected by centrifugation and washed with sterile water to remove the excess glutaraldehyde. Then the cells obtained from $50 \mathrm{~mL}$ culture medium $(0.38 \mathrm{~g}$ weight wet) were incubated with each carrier suspended in $10 \mathrm{~mL}$ water. The carriers were collected by centrifugation and washed with sterile water and used for inoculating $25 \mathrm{~mL}$ production medium (Abdel-Naby, 1993).

\section{Adsorption on chitosan}

One gram of chitosan (flakes $1 \times 1 \mathrm{~mm}$ ) was dissolved in $100 \mathrm{~mL}$ of $0.01 \mathrm{M} \mathrm{HCl}$. Then the wet cell pellets obtained from $50 \mathrm{~mL}$ culture medium ( $0.38 \mathrm{~g}$ weight wet) were mixed with $100 \mathrm{~mL}$ of the previous chitosan solution. The beads were obtained by adjusting the $\mathrm{pH}$ value of the mixture to 7.0 with $0.01 \mathrm{M} \mathrm{NaOH}$, washed with distilled water and used for inoculating of $25 \mathrm{~mL}$ production medium.

\section{Production of alkaline protease by immobilized cells}

\section{Batch experiment}

Batch experiment of the immobilized cells was performed in 250-mL Erlenmeyer flasks each containing $25 \mathrm{~mL}$ of sterile medium. The flasks were inoculated with the calculated amount of beads. Fermentation was conducted at $37^{\circ} \mathrm{C}$ for $96 \mathrm{~h}$ in a rotary shaker regulated at $180 \mathrm{rpm}$. The cultivation medium was filtered off and the clear filtrate was taken for enzyme assay.

\section{Repeated batch experiment}

The experimental set up was similar to that of batch cultures. Every $96 \mathrm{~h}$, immobilized cell beads were removed, washed with saline and recultivated into fresh medium. The process was repeated for several batches till the beads started disintegrating. 


\section{Continuous production using bioreactor}

The bioreactor as shown in Figure 1 is a glass column of $1.8 \mathrm{~cm}$ diameter and $320 \mathrm{~cm}$ in length. The bioreactor was filled with $17.9 \mathrm{~g}$ of freshly prepared immobilized beads comprising $7.6 \mathrm{~g}$ of wet weight bacterial cells, the working volume of reactor was about $232 \mathrm{~mL}$. The fresh medium was introduced from the bottom of the reactor and control by a peristaltic pump. Air was admitted through a sterile air filter from the bottom of the reactor and the air flow was optimized at $0.3 \mathrm{v} / \mathrm{v} / \mathrm{min}$ using rotameter. The effluent was collected in a holding tank. The system was considered to be in a steady state only after at least 5 residence times (replacement volumes).

\section{RESULTS AND DISCUSSION}

\section{Production of alkaline protease in batch culture}

For this purpose the same amount of bacterial cells were immobilized by different methods on different carriers. The specific productivity and the effectiveness factor are the key parameters to select the suitable method and carrier for immobilization process.

The results showed that the activity of the immobilized cells was lower than the free cells and the effectiveness factor of the immobilization was less than one. Similar observations were reported by Jamuna and Ramakrishna (1992). Zaghloul et al. (2002) suggested that $B$. subtilis cells appeared to be more active than alginate immobilized cells. This might be due to the fact that viable cells of the free culture were little higher than that of the immobilized culture. This is because they represent a heterogeneous catalysis fermentation, in which the activity or rather synthesis of primary or secondary metabolites is dependent upon the mass transported and adequate oxygen supply. Also, the nutrients are lowering accessible to the immobilized cells. On the other hand, immobilization process leads to

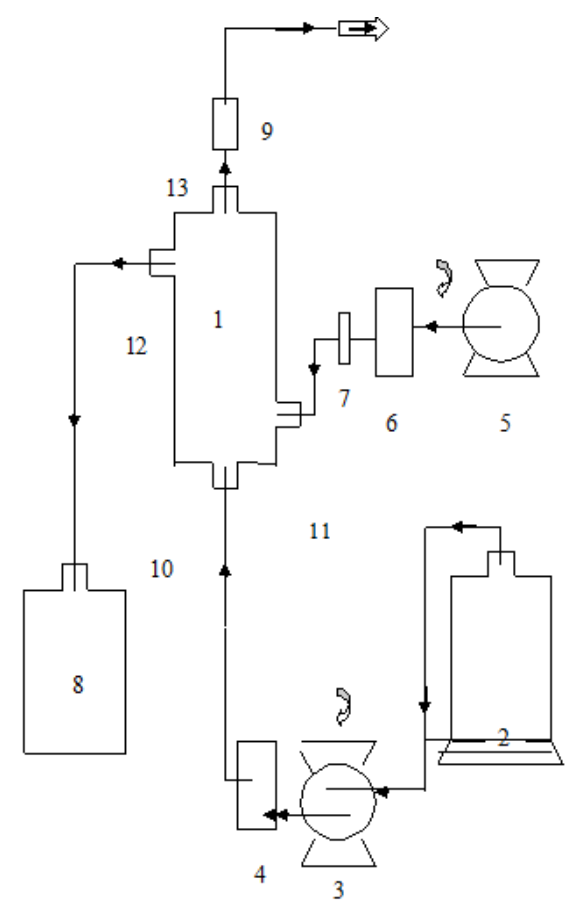

Figure 1: Schematic representation of the continuous fermentation system

1 Bioreactor with the immobilized beads

8 Product collection vessel

2 Medium feed reservoir 9 Outlet air filter

3 Peristaltic pump 10 Medium inlet

4 Flow rat regulator 11 Air inlet

5 Air pump 12 Product outlet

6 Rotameter 13 Air outlet

7 Air filter

Table 1: Production of alkaline protease in batch culture by free and immobilized B. licheniformis ATCC 21415 cells

\begin{tabular}{lccc}
\hline Carriers & $\begin{array}{c}\text { Caseinase activity } \\
(\mathrm{U} / \mathrm{mL})\end{array}$ & $\begin{array}{c}\text { Specific productivity } \\
(\mathrm{U} / \mathrm{g} \text { wet cells/h) }\end{array}$ & $\begin{array}{c}\text { Effectiveness factor of } \\
\text { immobilization }\end{array}$ \\
\hline Free cells & 14.33 & 9.82 & 1.00 \\
Immobilized cells & & & \\
I. Entrapment & 6.15 & 4.21 & 0.43 \\
$\quad$ Agar 3\% & 6.21 & 4.26 & 0.43 \\
$\quad$ Ca-alginate 3\% & 5.47 & 3.75 & 0.38 \\
$\quad$ k-carrageen 3\% & & & \\
II. Covalent binding & 8.50 & 5.83 & 0.59 \\
$\quad$ Loofa & 6.45 & 4.42 & 0.45 \\
$\quad$ Sponge & 1.31 & 0.89 & 0.09 \\
$\quad$ Stainless steel & 9.00 & 6.17 & 0.64 \\
$\quad$ Wool & & & 0.57 \\
III. Adsorption & 8.13 & 5.57 & \\
Chitosan & . & &
\end{tabular}

${ }^{*}$ The activity of immobilized cells/the activity of the same amount of free cells. 
changes in the micro environmental conditions, and some metabolic and morphological alteration in the cells may occur. The results in Table 1 showed that the highest specific productivity $(6.17 \mathrm{U} / \mathrm{g}$ wet cells/h) was reached by covalent binding of $B$. licheniformis ATTC 21415 cells on wool. Immobilization on wool showed the highest effectiveness factor of immobilization (0.64). Wool is considered a new attractive carrier for immobilization and because of its low cost, non-toxic and available.

\section{Production of alkaline protease by repeated batch fermentation}

Batch culture is a common mode for commercial fermentation in addition to fermentation time; however the production cycle also includes turnaround time (needed for sterilization, inoculation, turnaround etc.). This leads to a reduction in overall productivity and add to production costs. Therefore the possibility of multiple uses (repeated batch) of $B$. licheniformis ATTC 21415 wool immobilized cells was investigated. The results (Figure 2) indicated that wool immobilized cells retained their ability to produce alkaline protease consistently for 5 batches $(480 \mathrm{~h})$ with $57 \%$ residual productivity. Repeated batches of freely suspended cells had a significant decrease in residual productivity (35\%) after 2 cycles. This loss in activity may be due to destruction of cells as well as autolysis during the centrifugation and washing process. The results are in agreement with those obtained by Beshay and Moreira (2003). They also reported on a rapid decrease in protease production by free Teredinobacter turnirae cells in the early cycles as compared to porous sintered glass immobilized cells. Adinarayana et al. (2005) reported that repeated batch fermentation with $B$.subtilis $P E-11$ alginate beads were successfully run for 9 batches ( 9 days).

\section{Continuous production of alkaline protease}

The fermentation was conducted at $37^{\circ} \mathrm{C}$ and carried out in batch operation for $24 \mathrm{~h}$, and then the continuous operation was started at different dilution rates $(0.1-0.7 / \mathrm{h})$. The results (Figure 3 ) indicated that the increase in dilution rate led to a gradual increase in reactor productivity and there was a pronounced decrease at higher dilution rates. Maximal enzyme activity $(9.9 \mathrm{U} / \mathrm{mL})$ was attained at a dilution rate of $0.1 / \mathrm{h}$ whereby the maximal reactor productivity $(3.32 \mathrm{U} / \mathrm{mL} / \mathrm{h})$ was obtained at a dilution rate of $0.4 / \mathrm{h}$. Christiansen and Nielsen (2002) found that the maximal production of extracellular $B$. clausii protease was reached at a dilution rate of $0.14 / \mathrm{h}$ and it was constant in the range from 0.14 to $0.17 / \mathrm{h}$. The kinetic parameters of the reactor with different dilution rates (data not shown) indicated that the specific productivity increased with the increase in dilution rate up to $0.4 / \mathrm{h}$ which gave maximal specific productivity (100.47 $\mathrm{U} / \mathrm{g}$ wet cells/h). The higher dilution rate led to decrease in specific productivity $(88.93 \mathrm{U} / \mathrm{g}$ wet cells $/ \mathrm{h})$. This trend was expected since the contact time between the medium and the immobilized cells was decreased as the dilution rate increased. Operational stability of the bioreactor was studied. As shown from the results in Table 2, the reactor was able to keep producing alkaline protease enzyme (8.1 $\mathrm{U} / \mathrm{mL}$ ) for $120 \mathrm{~h}$. After 5 days there was a gradual decrease in the enzyme level to $1.7 \mathrm{U} / \mathrm{mL}$ after $216 \mathrm{~h}(9$ days) of the operation.

Table 2: Production of alkaline protease by wool immobilized B.licheniformis ATCC 21415 cells in packed-bed bioreactor at dilution rate $0.4 / \mathrm{h}$

\begin{tabular}{ccc}
\hline $\begin{array}{c}\text { Time } \\
(\mathrm{h})\end{array}$ & $\begin{array}{c}\text { Caseinase activity } \\
(\mathrm{U} / \mathrm{h})\end{array}$ & $\begin{array}{c}\text { Relative productivity } \\
(\%)\end{array}$ \\
\hline 24 & 8.3 & 100.00 \\
48 & 8.3 & 100.00 \\
72 & 8.2 & 98.80 \\
96 & 8.1 & 97.60 \\
120 & 8.1 & 97.60 \\
144 & 6.0 & 72.3 \\
168 & 4.4 & 53.00 \\
192 & 3.0 & 36.10 \\
216 & 1.7 & 20.50 \\
\hline
\end{tabular}

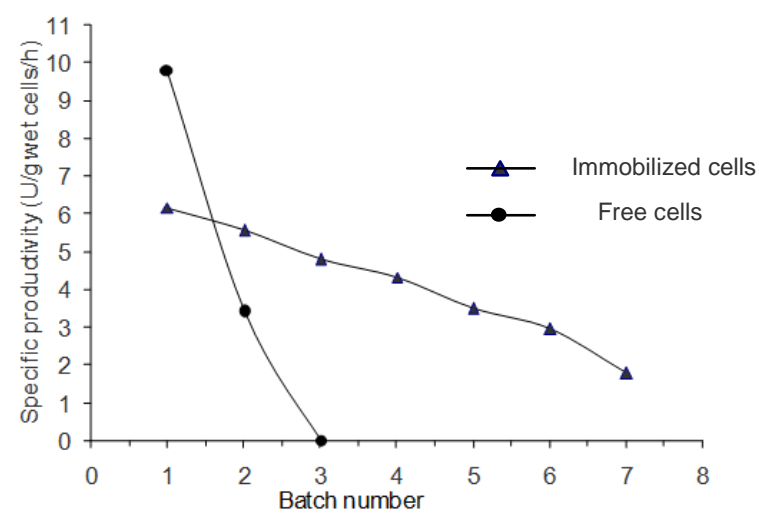

Figure 2: Repeated batch fermentation for alkaline protease production by free and wool immobilized B.licheniformis ATCC 21415 cells

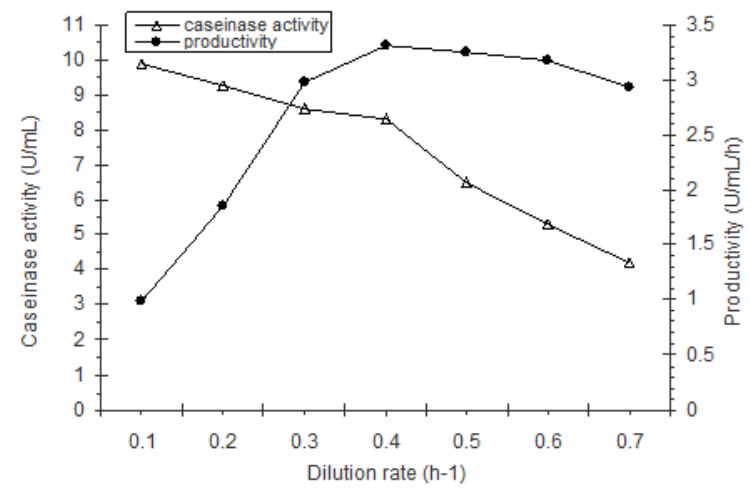

Figure 3: Continuous production of alkaline protease enzyme by wool immobilized B.licheniformis ATCC 21415 cells 


\section{CONCLUSIONS}

Immobilization of B.licheniformis ATTC 21415 cells on a new carrier (wool) by covalent binding is a promising method for alkaline protease production. Immobilized cells under continuous operation in the bioreactor resulted in a specific productivity of $118.2 \mathrm{U} / \mathrm{g}$ wet cells/h which is 12 24 times higher than the other systems.

\section{ACKNOWLEDGMENT}

The authors thanks the Academy of Scientific Research and Technology for supporting their search through project titled "Application of the recent approaches to improve the activity and stability of some microbial enzymes of economical importance".

\section{REFERENCES}

Abdel-Naby, M. A. (1993). Immobilization of Aspergillus niger NRC107 xylanase and $\beta$-xylosidase and properties of the immobilized enzyme. Applied Biochemistry and Biotechnology 38, 69-81.

Adinarayana, K., Bapi Raju, K. V. V. S. N. and Ellaiah P. (2004). Investigation on alkaline protease production with $B$. subtilis PE-11 immobilized in calcium alginate gel beads. Process Biochemistry 39, 1331-1339.

Adinarayana, K., Jyothi, B. and Ellaiah, P. (2005). Production of alkaline protease with immobilized cells of Bacillus subtilis PE-11 in various matrices by entrapment technique. AAPS PharmSciTech, 6 (3) Article 48,391-397.

Bergkvist, R. (1963). The proteolytic enzyme of Aspergillus oryzae methods for the estimation and isolation of the proteolytic enzymes. Acta Chemica Scandinavica 17, 1521-1540.

Beshay, U. (2003). Production of alkaline protease by Teredinobacter turnirae cells immobilized in $\mathrm{Ca}$ alginate beads. African Journal of Biotechnology 2(3), 60-65.

Beshay, U. and Moreira, A. (2003). Repeated batch production of alkaline protease using porous sintered glass as carriers. Process Biochemistry 38, 14631469.

Cheetham, P. S. J., Garrett, C. and Clark, J. (1985). Isomaltulose production using immobilized cells. Biotechnology and Bioengineering 27, 471-481.

Christiasen, T. and Nielsen, J. (2002). Production of extracellular protease and glucose uptake in Bacillus clausii in steady-state and transient continuous. Journal of Biotechnology 97, 265-273.

Galazzo, J. L. and Bailey, J. E. (1990). Growing Saccharomyces cerevisiae in calcium alginate beads induces cell alteration which accelerates glucose conversion to ethanol. Biotechnology and Bioengineering 36, 417-426.

Guo, Y., Lou, F., Peng, Z. Y. and Yuan, Z. Y. (1990). Kinetics of growth and $\alpha$-amylase production of immobilized Bacillus subtilis in an airlift bioreactor. Biotechnology and Bioengineering 35, 99-102.

Harwood, C. R. (1992). Bacillus subtilis and its relatives: molecular biological and industrial workhorses. Trends Biotechnology 10, 247-256.

Helmo, K., Winther, N. M. and Emborg, C. (1985). Protease productivity in chemostat fermentation with retention of biomass on suspended particles. Enzyme Microbial Technology 7, 443-444.

Jamuna, R. and Ramakrishna, S. V. (1992). Continuous synthesis of thermostable $\alpha$-amylase by Bacillus cells immobilized in calcium alginate. Enzyme Microbial Technology 14, 36-41.

Joo, H. S., Kumar, C. G., Park, G. C., Kim, T. K., Paik, S. R. and Chang, C. S. (2002). Optimization of the production of an extracellular alkaline protease from Bacillus horikoshii. Process Biochemistry 38,155-159.

Karandikar, S., Prabhune, A., Kalele, S. A., Gosavi, S. W. and Kulkarni, S. K. (2006). Immobilization of thermotolerant Kluyveromyces marxianus on silica aerogel for continuous production of invertase syrup. Research Journal of Biotechnology 1(2), 16-19.

Lowry, O. H., Rosebrough, N. J., Farr, A. L. and Ranall, R. T. (1951). Protein measurement with the folin phenol reagent. Journal Biological Chemistry 193, 265-273.

Prabakaran, G. and Hoti, S. L. (2008). Immobilization of alginate-encapsulated Bacillus thuringiensis var israelensis containing different multivalent counterions for Mosquito control. Current Microbiology 57, 111-114.

Singh, J., Vohra, R. M. and Sahoo, D. K. (2004). Introduced production of alkaline proteases by Bacillus sphareicus using fed-batch culture. Process Biochemistry 39, 1093-1101.

Zaghloul, T. I., Hendawy, H. M., El-Assar, S. and Mostafa, M. H. (2002). Enhanced stability of the cloned Bacillus subtilis alkaline protease gene in alginate-immobilized $B$. subtilis cells. Enzyme and Microbial Technology 30, 862-866.

Zhang, X., Bury, S., DiBiasio, D. and Miller, J. E. (1989). Effect of immobilization on growth, substrate consumption in Escherichia coli. Journal Industrial Microbiology 4, 239-246. 